\title{
Analysis on Problems of De-administration in Institutes of Higher Education in China
}

\author{
Yi Miao \\ Doctor of College of Public Administration of Huazhong University of Science and Technology \\ Wuhan, China \\ Professor of College of Ideological and Political Education of North China University of Water Resources and Electric Power \\ Zhengzhou, China \\ e-mail:Miaoyi88888@126.com
}

\begin{abstract}
The administrative tendency is the product of the planned economy with Chinese characteristics. All public organizations are filled with administrative ranks, and institute of higher learning is one of them. However, during the establishment of systems of modern institutes of higher learning, de-administration attracts increasing concerns of thoughtful educators in education circle. Considerable suggestions have been made as to de-administration, yet the administrative tendency fails to get better but even worse, which shows the significance and urgency to solve the issue. This paper, from the point of the necessity and problems of de-administration in institutes of higher education, lays a theoretical foundation for feasible approaches of de-administration in higher education institutes so as to bring back the real academic freedom and independent system
\end{abstract}

Keywords-Institutes of Higher Education in China; De-administration; Analysis on Problems

The administrative tendency in institutes of higher learning means the institutes are structured and operated according to the structure and operation mode of administrative system, have the same property with government administrative departments on the system structure and operation. After the founding, China implements the overall administrative system, schools, banks, hospitals, even industry associations are included in the system. While the institutes of higher education are publicly controlled by administration, the official ranks in institutes of higher education strengthen the administrative tendency. Due to the administrative tendency of the administration in institutes of higher education, monopolization of resources allocation, the utilitarianism of academic activities and the lost of virtue of education, the genuine spirit of institutes of higher education is missing, and it is of great difficulty to build world class institutes of higher education. To give back academic freedom as well as academic prosperity to higher education institutes, the implementation of de-administration is of extreme urgency.

\section{NeCESSITY OF DE-ADMINISTRATION IN INSTITUTES OF HiGHER EDUCATION}

\section{A. Requirements of educational mission and objective of higher education institutes}

Currently, due to the rapid development of social and economic globalization, political multi-polarization and cultural diversity, we propose to practice the quality-oriented education instead of the examination-oriented education. However, it brings little influence on the objective of modern higher education; the administrative tendency in institutes of higher education still prevails. As a result, those institutes lost their independence and autonomy; the government makes decisions on the enrollment as well as on the teaching and academic resources; and then the conflicts between the administrative power and the academic power are rising and intensified. All these have betrayed the objective and mission of modern higher education institutes to cultivate creative talented people and to build research institutes. As a result, a sense of distrust is generated among the public, and institutes of higher education become a synonym for utilitarianism in pursuit of fame and wealth in people's heart.

\section{B. Requirements of the basic rule of education and of the academic discipline}

Since institute of higher education is affiliated to Higher Education Implementation Organization of National Higher Education System, it shall be operated in accordance with the development law of higher education, as the global existence. The development of education shall firstly obey the basic rule of education itself, namely, conditions of education, to offer the educated quality education; and then keep pace with the social and economic development by analyzing the social demands for talents, including the quantity, category and structure[1]; moreover, higher education must satisfy the requirements of social and economic development and fit in materials conditions provided, which is to follow the law of social and economic development.

\section{Make institutes of higher learning have real decision-making rights on the seven matters including enrollment, setup of specialties and academic research and so on.}

The monopolization and the intervention of government on matters of institutes of higher education take away the autonomy, independence and initiative and make the institutes devoid of academic vitality. The bureaucratic administration incurred by the administrative ranking in the institutes makes the teaching and scientific research even worse. Although documents related to reforms have been issued by our 
government, the strong intervention and our mighty government lead to the dependency of all organizations for survival. In case the institute is deprived of ranks, they can not obtain enough education funds and academic resources; therefore, the de-administration plan of institutes of higher education is an empty talk, there is still a long way to go.

Summing up the above, the de-administration in institutes of higher education is imperative under such situation. Only by actively implementing the reform on the administration system in institutes of higher education can institutes of higher learning achieve the objective of exploring, pursuing, defending and spreading the truth. And then, it may shoulder the responsibility of guiding the social values and social behaviors and become the irreplaceable education institute and academic organization to improve the quality of people and to promote the development of social civilization and national development. However, there are still a great number of problems about the de-administration in institutes of higher education.

\section{ANALYSIS ON PROBLEMS OF DE-ADMINISTRATION IN INSTITUTES OF HIGHER EDUCATION}

\section{A. Deeply-rooted Academic Official-rank-oriented Thought}

"Academic official-rank-oriented thought" refers to a value standard of life of teachers in higher education institutes who take "official rank" as their pursuit. And its essence is that the capital of power can make the tangible assets, including money, as well as the intangible assets, for instance, the social status, available.[2] Therefore, under this politic atmosphere, a lot of organizations which shall have nothing to do with officialdoms, such as scientific and research institutions as well as institutes of higher education, are influenced by the administrative tendency. Then, considerable quantity of scientific research workers and teachers in institutes of higher education are busy at pursuing the official position, quality of academic papers or research projects of higher education institutes goes from bad to worse consequently. The reason why so many experts and scholars are strongly influenced by the "academic official-rank-oriented thought" is that, under the current academic system, officials have a lot of privileges: possessing the right of speak on resources, being allocated more scientific research funds and achieving more scientific research projects, and having the opportunity to conduct state-financed "academic investigations" abroad, etc. The academic officials or the powerful man in research institutions is entitled to allocate resources for scientific researches and to formulate various "rules of game" for the researches so that all scientific researches are controlled by powers; hence, if there is no power, there are no resources. The "academic-rank-oriented thought" has serious impeded the healthy development of scientific researches. On one hand, having been engaged in various conferences and reports as well as social intercourse, the scientific researcher officials have no time and energy or even no interests in the scientific researches; on the other, with power in control, some scientific researchers intentionally or unintentionally, by taking the advantages of their power, keep the funds in institutions where they are but not allocate the funds to others who really do the research work. The academic official-rank-oriented thought will definitely incur academic corruptions and exert negative effects on the influence of higher education institutes as well as the its image in people's heart.

\section{B. Objection and resistance from beneficiaries in institutes of higher education}

Professor Chen Danqing thinks that, the core of administrative tendency is interest and the common pursuit to interest results in utilitarianism tendency in universities. The utilitarianism is so popular in institutes of higher education that all the people are linked to interest. Also, it is such interest and "latent rules" in pursuing interest that make the people in universities purposefully accept and obey administrative tendency. They acquire their interests in the course of accepting and obeying this tendency, and in order to acquire more interests, they spare no effect to promote the development and deepening of administrative tendency. Therefore, the first thing to be weakened in the course of de-administration reform in institutes of higher education is the interest of beneficiary (especially college leadership). For example, when professor Ji Baocheng, the president of Renmin University of China, made his statement with respect to the key questions and hot questions involved in China's educational reform in 2010, he said, "since administrative hierarchy is deemed as the evaluation criterion by all the people, the cancellation to administrative hierarchy would not only a depreciation to education but also result in separation of universities from society." [3]However, the value of a university doesn't depend on administrative hierarchy but the level of scholarship. In many universities, professors have already become the group with lowest rank so that what teachers or professors pursue aren't knowledge and contributions but post and rank. Then, what is the meaning and value to establish institutes of higher education? Moreover, someone, without any care about scholarship, just pursues the "post" without any hesitation; what's more, there has occurred the situation that "forty professors fight for one post of section chief'. What people respect isn't knowledge but post, and this is the consequence of educational administrative tendency.

In the system of higher education, the administrative system has created a pyramid-type structure: the higher a man's rank is, the more resources he controls, the more interests he gets and the weaker his intention to make a reform; the lower a man's rank is, the fewer resources he controls, the fewer interests he gets and the stronger his intention to make a reform. However, the man holding the power doesn't want to make a reform while the man with stronger intention to make a reform doesn't have the right to speak[4]. Therefore, in order to promote the reform of de-administration, we should separate politics from universities, separate administration from operation and cancel the actually existing administrative hierarchy and administrative management mode step by step, which means knowledge is the most important and acknowledge that the teachers and professors working at the first line of teaching and scientific research represent the direction of academic development[5]. In the institutes of higher education, we should focus on knowledge and contributions instead of power and hierarchy. Therefore, de-administration in institutes of higher education means call back or limit the power of beneficiary, which is no doubt a 
threat to in-service presidents in institutes of higher education.

\section{The issues of relationships inside the institutes, between institutes and government, and between institutes and society}

To fully realize de-administration in institutes of higher education, firstly, we should solve the issue of the relationship between administrative power and academic power inside the institutes so as to make the institutes come back to the road of "faculty governance" and "academic-oriented development". Almost all the institutes in China has been highly influenced by administrative tendency so that administrative power is deemed to be superior to academic power, the main embodiments include: administrative department, occupying the leading role, decides the allocation of resources and handles important affairs; the power of academic committee has been largely weakened, it is just a decoration or can only provide advice for reference to important academic affairs, which overthrows the subject status of teachers and knowledge so as to make the talents who devote themselves to education and academic innovation be neglected gradually. Secondly, we should solve the relationship between institutes and government (especially the department responsible for education). At present, most of universities are established by government, since educational institutions are just subordinate body of government and government almost controls resources of institutes, including study resources and capital source, the institutes of higher education don't have decision-making right when facing the strong interference from educational authorities. By various projects such as enrollment plan, teaching and scientific research plan, degree spot, key discipline, key laboratory and base, and other means like evaluation and competition, the government intervenes university management in all aspects, which deepens the control of government to university and the rely of university on government. However, which kind of attitudes would government treat the institutes of higher education when they lose the corresponding status after de-administration? This is a problem long concerned by educational workers. What's more, we should solve the relationship between institutes and society, for example, after administrative level of institutes is abrogated; the president should sit in the back row in a meeting; the president should not walk VIP passage any more when taking plane and lose some opportunity to read and learn documents, once the presidents are deprived of the administrative power, how would they be linked with educational authorities[6].

The issues described above are main reasons that limit the development of higher education system in China. We have been committed to reforming institution system since university entrance examination was carried out again. However, the reform always can not fulfill its mission for many reasons, including the poor implementation of reform measures and alienation of system reform. And now, the administrative system only served for administration and power and administrative power became superior to academic power. Under this circumstance, the institutions of higher education would never become the subject of independent management and would lack the motivation to innovate in scientific research and to be responsible for society and students. Under the existing system, the institutes of higher education in China have completely lost the sense of independence, sense of responsibility and corresponding mechanism of independence management. Therefore, the system reform for institutes of higher education is inevitable and necessary.

\section{REFERENCES}

11] The Relationship between Urban-Rural Dual Structure and The Difficulty of Employment for College Students http://www.ai-space.cn/news/ NewsInfo.aspx?NewsID=15096. Sina News, 200-12-22

[2] Qiu Weiting. Bureaucrat-oriented Idea in Academic Circles[J]. Journal of Ningbo Radio \& TV University, 2008(6)

[3] Zi Buyu. President of Renmin University: Cancelling of Administrative Hierarchy In Institutions of Higher Education Would Despise Education. ChinaNet, 2010-3-7, http://www. china.com.cn/news/2010-03/07/content_19544570.htm,

[4] Li Kaisheng. Suggestions on Deepening of System Reform for Higher Education, 2009-3-9

[5] Baidu Encyclopedia, http://baike.baidu.com /view/3346296.htm?fr=ala0 1

[6] Guan Qingfeng, Sun Changluan, Zhao Yuanyuan. De-administration of Institutes of Higher Education Misgivings of President--"Relationship Between Society and Universities". Beijing Youth Daily, http://bjyouth.ynet.com/article.jsp?oid=64029506, 2010-03-13 